\title{
Menakar Produk Regulasi Pemerintah Kabupaten/Kota yang Kondusif bagi Investasi di Daerah
}

\author{
F.C. Susila Adiyanta \\ Pengajar Hukum Administrasi Negara FH Undip \\ susilafhundip@gmail.com
}

\begin{abstract}
The aim of regional autonomy and decentralization of the authority of the regency and city governments is to shorten the bureaucracy and optimize public services. In reality the products of regional regulations overlap their competencies, contradict the substance and material content with other regional regulations that are parallel, as well as the existing regulations above, which have implications for the emergence of the complexity of licensing bureaucracy, and uncertainty of society and business in carrying out activities business and investment activities, interests of capital owners, and business / trade, regional and national competitiveness. This study highlights the problems related to the relationship between the central and regional governments as determinants of regulations that are codified for investment, product characteristics of regency / city government regulations that are conducive to investment competitiveness in the region, and the competence of district / city governments in setting conducive regulations for investment using an empirical approach.

The conclusion of the results of this study is that the synergy between the central and regional governments is needed in designing conducive regulations to encourage the business and investment climate in the region, namely the product of regional regulations that do not conflict with the higher applicable regulations, efficient in tariff setting taxes, regional levies, and do not result in a high cost economy, do not result in double taxation with central taxes or with other regional taxes / levies, are not discriminatory, guarantee legal certainty and are equal in the eyes of the law, there is standard certainty services related to licensing); and regulations that are environmentally friendly, namely local regulations that support the management of natural resources well so that natural resources can be utilized optimally and sustainably. Recommendations in this study are: Central and regional governments must synergize and harmonize regulatory products at the central and municipal district levels, the regency and city governments must take the initiative to revise regulations on taxes and levies whose substance and material content are contrary to the regulations above, district governments and the city in formulating and determining the direction of reform policy and the implementation of governance in the regions must be oriented and refer to hierarchical relations between the central government and regional governments to support national development.
\end{abstract}

Keywords: District /City Government, Regulation, Investment

\section{Abstrak}

Tujuan otonomi daerah dan desentralisasi kewenangan pada pemerintah kabupaten dan kota diantaranya adalah memperpendek birokrasi dan mengoptimalkan pelayanan publik. Pada kenyataannya produk peraturan daerah yang tumpang tindih kompetensinya, bertentangan substansi dan materi muatannya dengan peraturan-peraturan daerah lainnya 
yang sejajar, maupun dengan peraturan-peraturan yang ada diatasnya, yang berimplikasi pada munculnya kerumitan birokrasi perijinan, dan ketidakpastian masyarakat dan dunia usaha dalam melakukan kegiatan usaha serta aktivitas investasi, minat pemilik modal, dan daya saing usaha/ perdagangan, perekomian daerah maupun nasional. Penelitian ini menyoroti permasalahan-permasalahan terkait dengan relasi antara pemerintah pusat dan daerah sebagai faktor penentu regulasi yang kodusif bagi investasi, karakteristik produk regulasi pemerintah kabupaten/kota yang kondusif bagi daya saing investasi di daerah, dan kompetensi pemerintah kabupaten/kota dalam menetapkan regulasi yang kondusif bagi investasi dengan menggunakan pendekatan empiris.

Kesimpulan dari hasil penelitian ini adalah sinergi antara pemerintah pusat dan daerah diperlukan dalam merancang regulasi yang kondusif untuk mendorong iklim usaha dan investasi di daerah, yaitu diperlukan produk peraturan daerah yang sifatnya tidak bertentangan dengan peraturan-peraturan yang lebih tinggi yang berlaku, efisien dalam penetapan tarif pajak, retribusi daerah, dan tidak mengakibatkan ekonomi biaya tinggi, tidak mengakibatkan pungutan berganda (double taxation) dengan pajak-pajak Pusat atau dengan pajak/retribusi daerah lainnya, tidak diskriminatif, menjamin kepastian hukum dan kedudukan yang sama di mata hukum, adanya kepastian standar pelayanan yang berkaitan dengan perizinan); dan perda yang ramah terhadap lingkungan, yaitu perda yang mendukung pengelelolaan sumber daya alam dengan baik agar sumber daya alam dapat dimanfaatkan secara optimal dan berkelanjutan. Rekomendasi pada penelitian ini yaitu: Pemerintah pusat dan daerah harus bersinergi dan mensikoronkan produk regulasi di tingkat pusat dan daerah kabupaten kota, pemerintah daerah kabupaten dan kota harus berinisiatif merevisi regulasi pajak dan retribusi yang substansi dan materi muatannya bertentangan dengan peraturan yang ada diatasnya, pemerintah kabupaten dan kota dalam merumuskan dan menetapkan arah kebijakan reformasi dan penyelenggaraan pemerintahan di daerah harus berorientasi dan mengacu pada hubungan hierarkhi antara pemerintah pusat dan pemerintah daerah untuk mendukung pembangunan nasional.

Kata Kunci: Pemerintah Kabupaten/Kota, Regulasi, Investasi

\section{A. Pendahuluan}

Penyelenggaraan otonomi daerah dengan titik berat otonomi pada daerah kabupaten/kota, menuntut adanya kesiapan sumber daya, sumber dana, responsibilitas, akuntabilitas, serta pranata sosial dari setiap pemerintah kabupaten/kota, sehingga mampu untuk menerima hak, wewenang, dan tanggung jawab yang lebih besar dari pemerintah pusat dan/atau pemerintah propinsi. Pemahaman akan tuntutan atas hak dalam mengelola rumah tangganya sendiri sangat wajar, sebab sistem pemerintahan sentralistik yang selama ini terjadi telah menguras kekayaan dan sumber alam yang dimiliki daerah. Pemerintah pusat pada masa Orde Baru sering bertindak kurang adil dalam pembagian pendapatan dan kekayaan yang ada di daerah-daerah. Hubungan keuangan pusat dan daerah dimanapun dipandang sangat menentukan dalam kemandirian otonomi daerah. 
Tujuan otonomi daerah dan desentralisasi kewenangan diantaranya adalah memperpendek birokrasi dan mengoptimalkan pelayanan publik. Dengan otonomi daerah, kepala daerah mempunyai tugas untuk menyelenggarakan pelayanan dan mewujudkan kesejahteraan publik. Pada kenyataannya yang terjadi justru adalah semakin memperpanjang proses birokrasi dan pelayanan publik. Berbagai distorsi dan anomali penggunaan kewenangan justru semakin meluas setelah dilaksanakannya otonomi dan desentralisasi kewenangan daerah. Potensi penyalahgunaan wewenang oleh penguasa daerah semakin marak, termasuk praktek-praktek koruptif yang semula sebagian besar hanya terkonsentrasi di pemerintahan pusat dilakukan pula di tingkat daerah ${ }^{1}$.

Persoalan lainnya yang muncul kemudian adalah minimnya sumber keuangan yang dimiliki daerah dibandingkan dengan yang dimiliki oleh pemerintah pusat. Pemerintah daerah yang tidak siap secara ekonomi, manajemen, dan birokrasi, serta kurang didukung sumber daya alam maupun sumber daya manusia, dalam proses transisi ini berupaya sekuat tenaga untuk membenahi daerahnya dengan bekal kekuasaan otonom dan desentralisasi kewenangan yang dimilikinya ${ }^{2}$.

Banyak produk peraturan daerah yang dibuat untuk memanfaatkan potensi sumber daya alam daerah, sehingga cenderung mengeksploitasi dan merusak alam serta lingkungan. Begitu pula daerah-daerah yang tidak mempunyai sumber daya alam, tetapi lebih banyak memiliki potensi sumber penerimaan keuangan dari sektor jasa, ekonomi, dan perdagangan, membuat peraturan-peraturan tentang pajak, retribusi atas jasa dan pelayanan publik yang justru menghambat kegiatan usaha, menjadi beban bagi masyarakat luas, yang pada sisi lain justru membuka peluang bagi aparat untuk memanfaatkan kesempatan atas kewenangan birokrasi yang dipegangnya ${ }^{3}$.

Berbagai peraturan daerah dibuat dengan tanpa adanya pertimbangan, tanpa koordinasi dengan pemerintah daerah, pemerintah pusat maupun lembaga-lembaga yang terkait dengan peraturan yang dibuat pemerintah daerah tersebut. Peraturan-peraturan dan kebijakan daerah yang dalam pembuatannya dimaksudkan untuk mengoptimalkan penerimaan daerah, justru berbalik arah menjadi tidak kondusif bagi investasi dan

1 Ibid.,, hlm. 45

2 Christian von Luebke (Australian National University) melalui penelitiannya (2006) juga membuktikan bahwa kepala daerah menjadi penentu kualitas peraturan daerah, Harian Bisnis Indonesia - Sabtu, 01 September 2007 - Hal. B11

${ }^{3}$ Pemerintah terus mengevaluasi peraturan daerah dan rancangan peraturan daerah yang membebani masyarakat dan pelaku usaha. Sampai pertengahan Juli, dari 7.200 peraturan yang dievaluasi Direktorat Jenderal Perimbangan Keuangan, sebanyak 2.000 peraturan tentang pungutan daerah diusulkan diusulkan untuk ditolak dan direvisi, Harian Koran Tempo, 23 Juli 2008 
pertumbuhan ekonomi. Pada sisi lain, kebijakan-kebijakan yang dibuat pemerintah daerah tersebut menjadi tidak populis dan cenderung membebani masyarakat.

Implikasi lebih lanjut dari munculnya berbagai produk peraturan daerah yang tumpang tindih, baik antara peraturan-peraturan daerah yang sudah ada, antara peraturan daerah dengan peraturan perundang-undangan yang diatasnya, serta bertentangan dengan peraturan-peraturan lain yang terkait pada akhirnya memunculkan kontroversi dan permasalahan dalam pelaksanaannya ${ }^{4}$. Semua itu berakibat pada pencabutan peraturanperaturan daerah yang bermasalah tersebut oleh pemerintah pusat. Tindakan pencabutan peraturan-peraturan daerah oleh pemerintah pusat ini tentu saja tidak serta merta ditaati oleh pemerintah daerah yang merasa telah memiliki kewenangan otonomi. Apalagi tidak ada peraturan yang menjadi landasan bagi pengenaan sanksi kepada pemerintah daerah yang tidak mencabut dan atau membatalkan peraturan yang dinilai bermasalah tersebut. Begitu pula tindakan pencabutan peraturan-peraturan daerah ini tidak pula mempengaruhi dan atau mengurangi beban masalah dan kerugian masyarakat luas yang terkena akibat dari peraturan daerah yang bermasalah tersebut. Pada dasarnya suatu peraturan daerah yang dicabut keberadaannya tidak mengakomodasi pemberian ganti rugi atas akibat dan dampak penetapan maupun pencabutannya kemudian.

Dampak lain dari keberadaan berbagai peraturan daerah yang tumpang tindih kompetensinya, dan bertentangan substansi dan materi muatannya dengan peraturanperaturan daerah lainnya yang sejajar, maupun dengan peraturan-peraturan yang ada diatasnya berimplikasi pada munculnya kerumitan birokrasi perijinan, dan ketidakpastian masyarakat -terutama dunia usaha- dalam melakukan kegiatan usaha serta aktivitas yang berkaitan dengan investasi, minat pemilik modal, dan daya saing usaha/ perdagangan yang menjadi penopang dan tumpuan pertumbuhan serta kemajuan perekomian daerah maupun nasional ${ }^{5}$.

Adanya duplikasi peraturan, pengenaan pungutan pajak dan retribusi ganda atas suatu obyek yang sama, pungutan-pungutan tidak resmi lainnya yang melekat dalam setiap

${ }^{4}$ Hingga akhir Desember 2008 terdapat 8.219 Peraturan Daerah (Perda) yang dievaluasi. Dari jumlah tersebut, sebanyak 34 persen atau sekitar ada 2.779 perda bermasalah dan dibatalkan atau direkomendasikan untuk direvisi. Dirjen Perimbangan Keuangan Depkeu Mardiasmo, di Jakarta, Rabu (31/12) menyebutkan bahwa hingga Desember ada 34 persen perda bermasalah.

Pemerintah menilai banyak peraturan daerah (perda) yang menghambat pembangunan daerah.Pasalnya, perda tersebut kontraproduktif untuk pengembangan ekonomi daerah. Direktur Pajak dan Retribusi Daerah Departemen Keuangan Budi Sitepu mengatakan pemerintah saat ini tengah memproses perdaperda bermasalah tersebut. Karena itu pemerintah akan memprioritaskan pencabutan perda yang berkaitan dengan investasi yang notabene sering dijadikan dalih pemerintah daerah untuk menarik pajak dan retribusi, Harian Kompas tanggal 28 Agustus 2009. 
proses administrasi dan birokrasi, proses perijinan yang berbelit-belit dan membutuhkan waktu lama, semuanya itu menjadi faktor tingginya biaya ekonomi (high cost economic), inefisiensi proses produksi yang pada akhirnya menjadi beban tidak saja bagi produsen, pengusaha, pelaku ekonomi, tetapi juga masyarakat luas. Semua permasalahan tersebut mempunyai implikasi yang saling terkait dalam skala regional maupun nasional. Harapan bahwa dengan sistem otonomi dan desentralisasi kewenangan daerah akan memperpendek birokrasi, mempercepat pertumbuhan ekonomi, meningkatkan jaminan pelayanan publik, serta terwujudnya pemerataan dan kesejahteraan masyarakat justru semakin menjauh dan menjadi angan-anngan belaka.

Berangkat dari deretan permasalahan tersebut di atas itulah, artikel ini disusun sebagai hasil penelitian mandiri yang menelaah tentang "Menakar Produk Regulasi Pemerintah Kabupaten/Kota yang Kondusif bagi Investasi di Daerah”, dengan titik tolak pada rumusan permasalahan yang terkait dengan investigasi relasi antara pemerintah pusat dan daerah sebagai faktor penentu regulasi yang kodusif bagi investasi, karakteristik produk regulasi pemerintah kabupaten/kota yang kondusif bagi daya saing investasi di daerah, dan kompetensi pemerintah kabupaten/kota dalam menetapkan regulasi yang kondusif bagi investasi

\section{B. Pembahasan}

1. Faktor Penentu Regulasi yang Kondusif bagi Investasi di Daerah: Relasi Kewenangan antara Pemerintah Pusat dengan Daerah Kabupaten/Kota

Pertumbuhan ekonomi bangsa Indonesia pada dasarnya ditunjang sepenuhnya oleh perkembangan ekonomi daerah. Kondisi demikian tersebut menuntut kewajiban pemerintah untuk secara strategis, melalui kebijaksanaan otonomi di bidang ekonomi untuk menghimpun sinergi dan peluang-peluang ekonomi di daerah dalam mewujudkan pembangunan yang dapat dirasakan oleh masyarakat daerah. Adanya kebijakan otonomi di bidang ekonomi merupakan dorongan bagi pertumbuhan ekonomi daerah ${ }^{6}$.

Hubungan keuangan pusat dan daerah dimanapun dipandang sangat menentukan dalam kemandirian otonomi daerah. Persoalan yang muncul kemudian adalah minimnya sumber keuangan yang dimiliki daerah dibandingkan dengan yang dimiliki oleh pemerintah pusat. Berdasarkan hal itu, maka inti hubungan keuangan pusat dan daerah adalah berkaitan

\footnotetext{
${ }^{6}$ Sambutan Menteri Dalam Negeri, Eksistensi dan Prospek Otonomi Daerah Pasca Orde Baru, Studi Nasional Mahasiswa FISIP Se Indonesia, Bandung, 2 Desember 1998, hlm. 15
} 
dengan perimbangan keuangan ${ }^{7}$, sedangkan yang dimaksud dengan perimbangan tidak lain adalah memperbesar sumber pendapata asli daerah sehingga lumbung keuangan daerah dapat berisi lebih banyak ${ }^{8}$. Kemampuan keuangan yang dimiliki daerah tersebut diharapkan akan mampu melaksanakan pembangunan dan meningkatkan kesejahteraan masyarakat di daerah.

Berkaitan dengan hal-hal sebagaimana tersebut di atas, maka wujud yang tepat hubungan keuangan antara pemerintah pusat dan pemerintah daerah harus dikembalikan pada pengertian dasar otonomi, yaitu kemandirian. Daerah harus memiliki keleluasaan untuk menentukan sendiri mengenai cara mengatur dan menurus urusan rumah tangganya sendiri. Perimbangan keuangan antara pemerintah pusat dan daerah tidak sekedar memperbesar sumber keuangan daerah, tetapi mengatur sistem keuangan daerah yang tetap menjamin kemandirian, keleluasaan, dalam mengatur dan mengurus sendiri rumah tangganya, meskipun uang tersebut berasal dari Pusat, seperti subsidi atau bantuan lainnya ${ }^{9}$.

Pembiayaan kegiatan pemerintahan daerah dilakukan menurut hubungan fungsi berdasarkan pembagian kewenangan tugas dan tanggungjawab antar tingkat pemerintahan. Penyelenggaraan tugas daerah dalam rangka pelaksanaan asas desentralisasi menjadi beban Anggaran Pendapatan dan Belanja Daerah (APBD), sedangkan tugas pemerintah pusat yang dilaksanakan perangkat daerah propinsi dalam rangka pelaksanaan asas dekonsentrasi dibiayai dari dana Anggaran Pendapatan Dan Belanja Negara (APBN) ${ }^{10}$.

Di tingkat propinsi, kewenangan bidang pemerintahan yang bersifat lintas kabupaten dan kota menjadi tanggung jawab propinsi, misalnya adalah kewenangan di bidang pekerjaan umum, perhubungan, kehutanan, perkebunan, disamping kewenangan bidang pemerintahan tertentu lainnya. Bidang lainnya yang tetap menjadi kewenangan pemerintah pusat adalah mencakup : ${ }^{11}$

1) Perencanaan nasional dan pengendalian pembangunan sektoral dan nasional secara makro;

2) Kebijakan dana perimbangan keuangan;

7 Yang dimaksud dengan perimbangan keuangan menurut Bagir Manan dalam makalahnya "Hubungan Pusat dan Daerah ....., Ibid., hlm. 9 , tidak lain adalah memperbesar sumber pendapata asli daerah sehingga lumbung keuangan daerah dapat berisi lebih banyak. Kemampuan keuangan yang dimiliki daerah tersebut diharapkan akan mampu melaksanakan pembangunan dan meningkatkan kesejahteraan masyarakat di daerah.

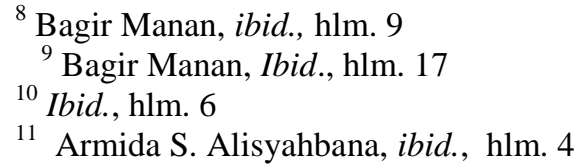


3) Kebijakan sistem administrasi negara dan lembaga perekonomian negara;

4) Kebijakan sistem pembinaan dan pemberdayaan sumberdaya manusia;

5) Kebijakan pendayagunaan teknologi tinggi dan strategis, pemanfaatan kedirgantaraan, kelautan, pertambangan, kehutanan, dan lingkungan hidup;

6) Kebijakan konservasi;

7) Kebijakan standardisasi nasional.

Pelaksanaan tugas pembantuan, menurut UU No. 22 Tahun 1999 jo UU No. 22 Tahun 2004 sebagaimana telah diubah dengan UU No. 22 Tahun 2004 tentang Pemerintah Daerah, dimungkinkan tidak hanya dari pemerintah kepada daerah, tetapi juga dari pemerintah dan daerah kepada desa, yang disertai dengan pembiayaan, sarana dan prasarana, serta sumber daya manusia dengan kewajiban melaporkan pelaksanaan dan mempertanggungjawabkan kepada yang menugaskannya ${ }^{12}$.

\section{Karakteristik Yuridis Produk Regulasi Pemerintah Kabupaten/Kota yang Kondusif bagi Investasi}

Kehadiran investasi swasta semakin dirasakan penting sebagai titik ungkit pertumbuhan ekonomi daerah dan nasional. Kapasitas fiskal negara untuk membiayai investasi produktif maupun belanja konsumsi pemerintah secara riil semakin terbatas,sehingga sulit untuk terus menjadi andalan pemerintah dalam mendukung pendanaan pembiayaan pembangunan. Sementara itu konsumsi masyarakat, yang secara agregat telah memberikan kontribusi yang besar bagi pertumbuhan ekonomi pada beberapa tahun terakhir sebenarnya menjadi faktor yang perlu dicermati karena kondisi tersebut lebih hanya sebagai simbol struktur ekonomi yang rapuh dan kurang merefleksi kondisi riil di masyarakat, yaitu berkaitan dengan faktor pengangguran dan disparitas daya beli ${ }^{13}$.

Berbagai kendala yang dapat menghambat iklim usaha, minat investasi, dan daya saing usaha di daerah secara umum pada kenyataannya dipengaruhi oleh tingkat keberhasilan suatu daerah dalam menyusun dan melaksanakan kebijakan publik dengan kaualitas dan kapasitas pelayanan pemerintahan yang dapat memenuhi ekspektasi minimum para pelaku usaha.

\footnotetext{
12 Penjelasan UU No. 22 Tahun 1999 jo UU No. 22 Tahun 2004 sebagaimana telah diubah dengan UU No. 22 Tahun 2004 tentang Pemerintah Daerah Bagian Umum Angka 1. tentang Dasar Pemikiran

${ }^{13}$ Panduan Perancangan dan Review Peraturan Daerah yang Ramah Investasi Proyek Perbaikan Iklim Investasi Daerah Melalui Penerapan Sistem Perijinan Terpadu dan Penyempurnaan Kualitas Peraturan Daerah, Proyek Bersama KPPOD-European Commision, dan Asosiasi Pemerintahan Kota Seluruh Indonesia, Jakarta 2008, hlm. 4
} 
Dalam konteks otonomi daerah, kualitas kebijakan publik yang dimaksud adalah terutama menyangkut kerangka regulasi tentang kegiatan usaha yang lebih dikenal sebagai peraturan daerah (perda) dan berbagai peraturan organik lainnya sebagai peraturan pelaksanaannya (peraturan kepala daerah dan keputusan kepala daerah). Terhadap berbagai kebijakan tersebut, para pelaku usaha berharap akan adanya substansi tentang pengaturan yang secara generik sering disebut sebagai peraturan daerah yang ramah investasi.

Melalui peraturan daerah (perda), pemerintah daerah merumuskan berbagai kebijakan pembanguan daerahnya, salah satunya adalah kebijakan untuk memacu pertumbuhan perekonomian di daerahnya. Bagi pengusaha atau investor, perda sebagai acuan pelaksanaan peraturan-peraturan daerah lain di bawahnya menjadi penting keberadaannya karena dalam menjalankan usahanya di daerah, para pengusaha atau investor akan selalu bersentuhan dengan pelaksanaan berbagai Perda, terutama yang berkaitan dengan dunia usaha.

Para pengusaha atau investor sudah pasti mengharapkan adanya perda-perda yang kondusif dan mendukung usaha atau investasi mereka di daerah. Perda-perda yang kondusif bagi dunia usaha dan investasi tentunya menjadi salah satu daya tarik tersendiri bagi para pengusaha atau investor untuk berinvestasi di daerah tersebut. Pada gilirannya, kegairahan para pengusaha atau investor untuk melakukan usaha atau berinvestasi di suatu daerah dapat menjadi salah satu pendorong bagi pertumbuhan perekonomian daerah.

Tabel

Kemudahan Berinvestasi di Indonesia Dibandingkan dengan Negara-negara ASEAN Lainnya
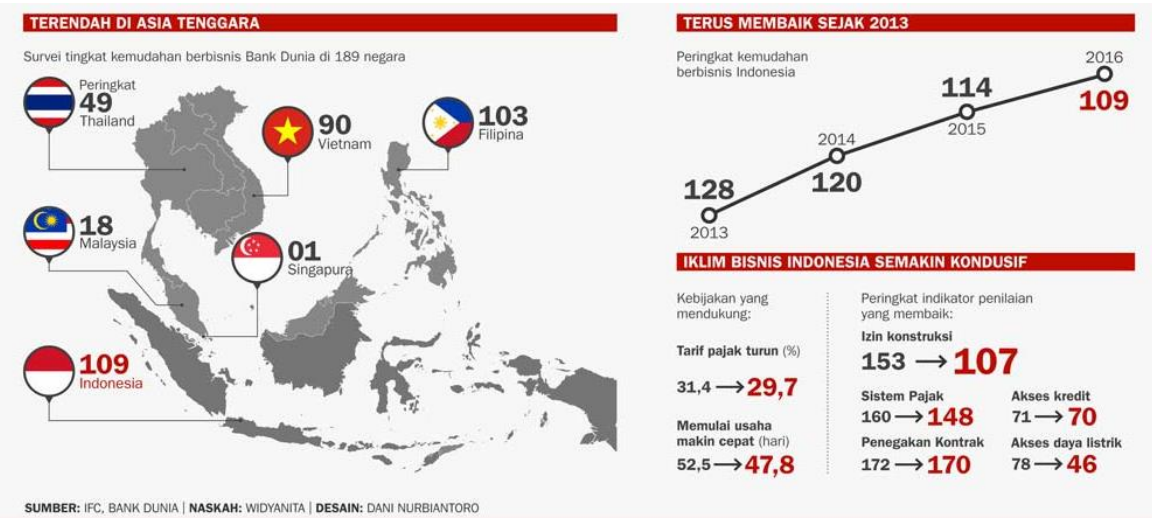

Sumber Data: https://katadata.co.id/infografik/2015/11/12/indonesia-masih-tertinggal-di-asean

Oleh KPPOD disebutkan bahwa perda yang mendukung pertumbuhan ekonomi daerah -salah satu kriterianya- adalah perda yang kondusif terhadap penciptaan iklim usaha dan investasi yang sehat dan efisien di daerah. Disebutkan pula bahwa suatu perda yang 
kondusif terhadap penciptaan iklim usaha dan investasi yang sehat dan efisien di daerah adalah: ${ }^{14}$

a) Perda yang memiliki kesesuaian dengan peraturan-peraturan yang lebih tinggi yang berlaku;

b) Perda yang tidak mengakibatkan hambatan lalu-lintas distribusi barang dan atau jasa yang bersifat tarif maupun non tarif (tidak bertentangan dengan free internal trade principle);

c) Perda yang tidak mengakibatkan pungutan berganda (double taxation) dengan Pajak Pusat (PPh, PPN, PBB, dll) atau dengan Pajak/ Retribusi Daerah lainnya;

d) Perda yang besaran tarifnya berada dalam batas kewajaran sehingga tidak mengakibatkan ekonomi biaya tinggi;

e) Perda yang tidak diskriminatif. Perda yang tidak mengakibatkan penguasaan ekonomi pada kelompok-kelompok orang (tidak berpotensi menciptakan struktur pasar yang monopolis dan oligopolis);

f) Perda yang tidak mengharuskan atau mewajibkan investor untuk menjalin kemitraan dengan mitra lokal dari daerah yang bersangkutan;

g) Perda yang menjamin kepastian hukum dan menjamin setiap orang mempunyai kedudukan yang sama di mata hukum; (sanksi andministrasi dan atau pidana yang jelas dan berlaku bagi setiap orang, tanpa terkecuali);

h) Perda yang menjamin kepastian standar pelayanan (perda-perda yang berkaitan dengan perizinan), meliputi: kesederhanaan prosedur, kepastian atau batasan waktu pelayanan, tarif, dan institusi yang berwenang.

i) Perda yang ramah terhadap lingkungan, yaitu perda yang mendukung pengelelolaan sumber daya alam dengan baik agar sumber daya alam dapat dimanfaatkan secara optimal dan berkelanjutan.

Peraturan daerah dan produk-pruduk hukum daerah lainnya seperti keputusan kepala daerah/ walikota maupun segala bentuk perangkat regulasi yang di buat oleh pemerintah daerah bersama-sama dengan lembaga legislatif tingkat daerah pada dasarnya adalah instrumen legal pokok di tingkat provinsi/ kabupaten/ kota yang berkenaan dengan pengaturan, pembagian, dan pemanfaatan sumber daya lokal, organisasi pemerintahan, dan tata kehidupan sosial suatu daerah. Produk-produk peraturan daerah sebagai salah satu instrumen yang penting bagi dasar penyelenggaraan otonomi dan pelaksanaan kewenangan

\footnotetext{
${ }^{14}$ Laporan Program Review Perda Tahap II, Kerjasama KPPOD-PEG US AID, Agustus, 2002
} 
pemerintahan di daerah pada dasarnya harus mampu menjamin iklim dan lingkungan usaha yang kondusif bagi investor dalam menanamkan modalnya di daerah. Dengan demikian produk hukum yang dibuat di tingkat daerah ini dalam pembuatannya harus merujuk pada prinsip-prinsip demokrasi, peran serta masyarakat, pemerataan, dan keadilan, serta potensi keanekaragaman daerah, yang dilaksanakan dalam kerangka Negara Kesatuan Republik Indonesia.

Kondisi-kondisi dan kriteria berbagai produk peraturan daerah yang diperlukan untuk mendukung dan menjadikan suatu daerah kondusif bagi iklim investasi dan kegiatan usaha seperti telah disebutkan di atas dalam implementasinya tidak serta merta dapat diimplementasikan dengan baik dan memberi hasil yang optimal. Hal tersebut karena pada dasarnya masih banyak faktor lain yang bersifat komplek dan saling melengkapi dan mendukung bagi perkembangan dan kemajuan ekonomi suatu daerah, untuk itulah diperlukan partisipasi, kerjasama dan interaksi antara pemerintah, masyarakat, serta para pelaku usaha.

\section{Kompetensi Pemerintah Kabupaten/Kota dalam Menetapkan Regulasi yang Kondusif bagi Investasi}

Berdasarkan pemahaman bahwa keaneragaman istilah otonomi dipergunakan untuk maksud yang sama dalam penyelengaran dan tata kelola pemerintahan daerah, maka dapat dipakai sebagai acuan pengertian dari sistem otonomi mengenai batas-batas urusan rumah tangga daerah. Pada umumnya dikenal 2 (dua) sistem otonomi yang pokok, yaitu ${ }^{15}$ :

1) sistem otonomi materiil, atau pengertian rumah tangga materiil (materiele huishoudingsbegrip); dan

2) sistem ootonomi formil, atau pengertian rumah tangga formil (formeele huishoudingsbegrip).

Disamping itu, ada juga sistem lain yang merupakan kompromi antara kedua sistem itu, yaitu sistem otonomi riil, atau pengertian rumah tangga riil (riel huishoudingsbegrip).

Dalam pengertian sistem rumah tangga materiil, antara pemerintah pusat dan pemerintah daerah ada pembagian tugas (wewenang dan tanggungjawab) yang eksplisit (diperinci dengan tegas) dalam undang-undang pembentukan daerah. Dengan demikian artinya, otonomi daerah itu hanya meliputi tugas-tugas yang telah ditentukan satu per satu, jadi bersifat definitif. Hal itu berarti pula, apa yang tercantum dalam undang-undang

${ }^{15}$ Khrisna D Darumurti dan Umbu Rauta, op.cit., hlm. 15-19 
pembentukan daerah, tidak termasuk urusan pemerintah daerah otonom, melainkan urusan pemerintah pusat.

Cara penentuan otonomi seperti tersebut di atas didasarkan pada keyakinan bahwa perbedaan tugas yang asasi dalam menjalankan usaha-usaha memajukan kemakmuran dan kesejahteraan masyarakat antara pemerintah pusat/negara dengan daerah-daerah otonom. Di sini yang berbeda adalah materi yang yang menjadi obyek pengurusan dan pengaturan hukum dari masyarakat, oleh karena itu pengertian ini disebut sebagai sistem otonomi materiil.

Di dalam pengertian otonomi secara formil, tidak ada perbedaan sifat antara urusanurusan yang diselenggarakan oleh pemerintah pusat dan pemerintah daerah-daerah otonom. Hal ini berarti apayang dilakukan oleh negara (pemerintah pusat) pada prinsipnya dapat pula dilakukan oleh daerah-daerah otonom. Bila ada pembagian tugas (wewenang dan tanggung jawab), hal itu semata-mata disebabkan pertimbangan-pertimbangan yang rasional dan praktis, seperti efisiensi penyelenggaraan tugas pelayanan publik. Artinya, pembagian tugas itu tidaklah disebabkan materi yang diatur berbeda sifatnya, melainkan adanya keyakinan bahwa kepentingan daerah-daerah dapat lebih baik dan berhasil (lebih efisien) apabila diselenggarakan sendiri oleh daerah-daerah itu daripada oleh pemerintah pusat.

Di dalam sistem otonomi formal yang demikian ini, tidak terdapat perbedaan sifat materi yang diurus oleh daerah-daerah sebagai masyarakat hukum yang lebih kecil dan negara sebagai masyarakat hukum yang lebih besar. Perbedaan tugas daidakan secara formal dengan membuat bentuk-bentuk peraturan tertentu. Demikian pula dalam sistem otonomi formila tidak secara apriori ditetapkan apa yang termasuk dalam rumah tangga daerah otonom. Tugas dari daerah otonom secara normatif tidak terperinci di dalam undang-undang pembentukannya, melainkan ditentukan dalam suatu rumusan yang umum saja. Rumusan umum itu hanya mengandung asas-asas saja, sendangkan pengaturan yang lebih lanjut diserahkan kepada pemerintah daerah. Batasannya tidak ditentukan secara pasti bergantung pada keadaan, waktu, dan tempat. Jadi otonomi menurut sistem formil ini batasannya bertitik tolak pada peraturan yang dibuat oleh pemerintah yang ada di atasnya (rangorde regeling) ${ }^{16}$.

Berbeda dengan sistem otonomi yang telah dijelaskan sebelumnya, dalam sistem otonomi riil penyerahan urusan atau tugas dan kewenangan kepada daerah didasarkan pada faktor yang nyata atau riil, sesuai dengan kebutuhan atau kemampuan riil dari daerah maupun

\footnotetext{
${ }^{16}$ Jefferson Kameo, "Titik Berat Otonomi pada Daerah Tingkat II: sebuah Studi Kasus dengan Fokus Pada pada Dinas Pendapatan Daerah Tingkat II Kotamadia Daerah Tingkat II Salatiga, Fakultas Hukum UKSW, tidak dipublikasikan.
} 
pemerintah pusat serta pertumbuhan masyarakat yang terjadi. Karena pemberian tugas dan kewajiban serta wewenang ini didasarkan pada keadaan yang riil di dalam masyarakat. Hal ini membawa konsekuensi bahwa urusan/tugas yang selama ini menjadi wewenang pemerintah pusat diserahkan kepada pemerintah daerah, dengan memperhatikan kemampuan masyarakat untuk mengaturnya dan mengurusnya sendiri. Sebaliknya tugas yang telah menjadi wewenang daerah, suatu ketika, jika dipandang perlu dapat ditarik kembali oleh pemerintah pusat.

Sistem otonomi riil ini merupakan jalan tengah atau percampuran dari sistem otonomi materiil dan otonomi formil. Dalam arti, sistem ini mengandung anasir-anasir baik dari sistem otonomi materiil dan otonomi formil, sehingga dapat dikatakan merupakan sistem tersendiri ${ }^{17}$.

Terhadap sistem otonomi riil ini, Bagir Manan berpendapat bahwa sistem ini mempunyai ciri-ciri khas yang membedakannya dengan kedua sistem pokok otonomi, yaitu $^{18}$ :

a) menurut urusan pangkal yang ditetapkan pada saat pembentukan suatu daerah otonom, memberikan kepastian mengenai urusan rumah tangga daerah. Hal semacam ini tidak mungkin terjadi pada sistem rumah tangga formil.

b) Disamping urusan-urusan rumah tangga yang ditetapkan secara "materiil", daerah-daerah dalam rumah tangga riil dapat mengatur dan mengurus pula semua urusan pemerintahan yang menurut pertimbangan adalah penting bagi daerahnya sepanjang belum diatur dan diurus oleh pemerintah pusat atau daerah tingkat atas.

c) Otonomi dalam rumah tangga riil didasarkan pada faktor-faktor nyata suatu daerah. Hal ini memungkinkan perbedaan isi dan jenis urusan-urusan rumah tangga daerah sesuai dengan keadaan masing-masing.

Disamping ketiga di atas, dikenal juga apa yang disebut sebagai sistem residu (sisa). Dalam sistem ini secara umum telah ditentukan terlebih dahulu tugas-tugas yang telah menjadi wewenang pemerintah pusat, sedangkan sisanya menjadi urusan rumah tangga daerah. Kebaikan dari sistem ini terletak pada saat timbulnya keperluan-keperluan baru, pemerintah dapat dengan cepat mengambil keputusan dan tindakan yang dipandang perlu, tanpa menunggu perintah dari pemerintah pusat ${ }^{19}$.

\footnotetext{
${ }^{17}$ Koesoemahatmadja, Pengantar ke Arah Sistem Pemerintahan Daerah di Indonesia, Bina Cipta, Bandung, 1979, hlm. 20-21

${ }^{18}$ Bagir Manan, Hubungan antara Pusat dan Daerah Menurut UUD 1945, Pustaka Sinar Harapan, Jakarta, 1994, hlm. 32

${ }^{19}$ Josef Riwu Kaho, Prospek Otonomi Daerah di Negara Republik Indonesia, Penerbit Rajawali Pers, Jakarta, 1997, hlm. 15
} 
Dalam era desentralisasi dan otonomi daerah saat ini, setiap pemerintah daerah (pemda) diberikan kewenangan dan peran aktif membangun daerahnya. Harapannya, mendorong terciptanya pembangunan yang lebih merata di seluruh penjuru Indonesia sebagai salah satu jawaban atas ketimpangan pembangunan ekonomi antarwilayah di Indonesia selama puluhan tahun sebelumnya. Sejauh mana peran pemerintah daerah (pemda) dalam mendorong pembangunan di daerahnya masing-masing menjadi hal yang menarik untuk diketahui pada era otonomi daerah ini.

Sejak dierapkannya otonomi daerah, pemerintah daerah mempunyai kewenangan dan tanggungjawab dalam bidang-bidang pelayanan publik yang dulunya dilaksanakan oleh pemerintah pusat, yaitu: pekerjaan umum, kesehatan, pendidikan, pertanian, perhubungan, industri dan perdagangan, penanaman modal, lingkungan hidup, pertanahan, koperasi, dan tenaga kerja. Sebagai konsekuensi atas perluasan tugas-tugas kepada pemerintah daerah/ kota tersebut pemeritah daerah dituntut mempunyai kesiapan untuk siap menerima peningkatan tugas dan wewenang serta tanggung jawabnya sebagai daerah otonom.

Sementara itu kewenangan pemerintah pusat terbatas paada penanganan bidang politik luar negeri, pertahanan dan keamanan, peradilan, moneter/ fiskal, agama, dan bidang-bidang tertentu seperti: kebijakan perencanaan nasional, dana perimbangan, sistem administrasi negara, pembinaan dan pemberdayaan sumber daya manusia dan sumber daya alam, teknologi tinggi yang strategis, konservasi, dan standardisasi nasional. Sedangkan pemerintah propinsi, baik sebagai daerah otonom maupun wilayah administratif diberikan kewenangan dengan batasan hanya menyelenggarakan bidang-bidang urusan pemerintahan yang tidak mampu ditangani oleh pemeritah daerah atau bidang-bidang urusan pemerintahan yang sifatnya lintas daerah/ kota.

Desentralisasi yang diterapkan dalam penyelenggaraan pemerintahan di daerah memberikan pemerintah daerah kendali atas sumber daya keuangan yang sangat besar. Akan tetapi, sebagian besar kabupaten/ kota belum memiliki kapasitas untuk mengelola sumber daya tersebut secara transparan dan efisien. Dengan demikian adanya suatu sistem pemantauan kinerja pemerintah daerah (pemda) yang komprehensif dan handal akan menguntungkan bagi rakyat Indonesia. Setiap rakyat yang memiliki hak pilih dan kelompok advokasi dapat menggunakan informasi tersebut untuk meminta pertanggungjawaban pemerintah daerah (pemda) mereka - berdasarkan hal-hal yang wajar dalam jangka pendek dalam konteks Indonesia dan bukan berdasarkan praktik-praktik terbaik dari dunia internasional yang mungkin kurang realistis. 
Perbaikan aspek politik desentralisasi pada satu sisi telah mengalami peningkatan dan perbaikan, yaitu melalui aspek politik desentralisasi yang telah terwujud relatif memadai melalui pemilihan kepala daerah (pilkada) secara langsung. Demikian juga dengan adanya desentralisasi fiskal yang telah berjalan melalui perbaikan skema perimbangan keuangan antara pemerintah pusat dan daerah. Namun demikian, dalam penyelenggaraan desentralisasi daerah tidak terlepas dari aspek desentralisasi ekonomi, dalam pengertian bahwa fokus pemerintah daerah dalam usaha untuk perbaikan dinamika perekonomian daerah masih belum memadai. Masih amat sedikit daerah yang secara seruis menggunakan potensi fiskal, sumber daya alam (SDA), dan sumber daya manusia (SDM) yang yang dimiliki untuk memprioritaskan pembangunan ekonomi daerahnya. Demikian juga pemerintah pusat yang tidak secara optimal mendukung dalam pembagunan ekonomi daerah dalam mengoptimalkan ekonomi daerah ${ }^{20}$.

Arah kebijakan reformasi dan reorientasi penyelenggaraan pemerintahan di daerah yang telah dilaksanakan selama ini seharusnya mengacu pada berbagai permasalahan yang ada di daerah berkaitan dengan hubungan antara pemerintah pusat dan pemerintah daerah. Namun pada kenyataannya, dengan pendapatan daerah yang lebih kecil dibandingkan dengan biaya dan kebutuhan daerah,menghambat pemerintah daerah untuk melaksanakan tugas-tugas pemeritahn daerah yang terus semakin meningkat untuk memberikan pelayanan kepada masyarakat.

Kecilnya pendapatan daerah seringkali disebabkan oleh sumber penerimaan yang berasal dari kemampuan daerah sendiri (PAD, pendapata asli daerah) juga sangat kecil dan terbatas. Kondisi masih diperburuk dengan kebijakan pengaturan perimbangan keuangan antara pemerintah pusat dengan pemerintah daerah yang masih menggunakan pola bagi hasil pajak dan non pajak, subsisdi daerah otonom yang dalam pelaksanannnya kurang menguntungkan daerah yang mempunyai potensi sumbe daya dan kekayaan alam yang melimpah.

Dalam kaitan dengan berbagai permasalahan implementasi pelaksanaan otonomi daerah, tuntutan kemandirian daerah harus dipahami sebagai suatu perubahan kearah keleluasaan penyelenggaraan pemerintahan di daerah. Dengan demikian pemerintah daerah memperoleh ruang yang cukup untuk dapat mengelola segala keperluan daerah berdasarkan

${ }^{20}$ Salah satu contoh konkrit politik penyelenggaraan pemerintah daerah yang tidak mendukung pembangunan ekonomi ahíla dengan melakukan pemekaran daerah sehingga berakibat memperkecil skala ekonomi daerah dan menyulitkan optimalisasi pembangunan ekonomi daerah. 
kemampuan yang dimiliki oleh daerah. Ruang gerak yang diberikan kepada daerah memberikan kepercayaan kepada daerah untuk berperanserta dalam proses-proses perumusan dan pelaksanaan kebijakan di bidang pemerintahan, pembangunan daerah, dan kemasyarakatan yang sesuai dengan kebutuhan masyarakat daerah.

Kebiasaan masa lalu yang selalu menunggu petunjuk dari pemerintah pusat sebagian masih melekat pada aparat dan birokrasi di daerah perlu segera dihilangkan. Kesiapan sumber daya manusia di daerah dalam mengelola daerah masih perlu untuk ditingkatkan. Demikian pula dengan keleluasaan untuk berkreativitas pada tingkat daerah harus tetap memperhatikan kelayakan dan sesuai dengan ketentuan peraturan perudangundangan yang ada diaatasnya, kepentingan umum dan kesusilaan serta sesuai dengan prinsip-prinsip umum pemerintahan yang baik (the general principles of good government). Adanya kewenangan urusan pemerintah daerah yang begitu luas yang diberikan kepada daerah dalam rangka pelaksanaan otonomi daerah, pada satu sisi dapat merupakan berkat, namun pada sisi lain sekaligus merupakan beban yang pada giliriannya menuntut kesiapan daerah untuk dapat melaksanakan kewenangannya sesuai dengan yang diamanatkan oleh undang-undang.

Pada sisi lain, pemerintah kabupaten/kota yang berusaha mengusahakan kemadirian dalam pembiayaan keuangan daerah menggunakan kewenangannya untuk memperoleh dana dengan melakukan pungutan berupa pajak-pajak daerah dan retribusi. Penggunaan wewenang pemerintah daerah dan kota dengan regulasi pajak dan retribusi inilah salah satu faktor yang seringkali substansi dan materi muatannya bertentangan dengan peraturan yang ada diatasnya. Demikian pula dengan materi muatan peraturan daerah atau kebijakan yang substansinya bertentangan dengan hirarkhi peraturan perundang-undangan yang ada diatasnya.

Dari beberapa survey dan identifikasi atas beberapa peraturan daerah pada kabupaten dan kota yang dijadikan penelitian, beberapa peraturan daerah yang di batalkan diantaranya berkaitan dengan permasalahan yang menyangkut mengenai materi muatan peraturan daerah (perda) yang bertentangan dengan peraturan yang ada diatasnya maupun peraturan daerah (perda) yang materi muatannya bukan menjadi kewenangan pemerintah daerah atau kota sebagaimana ditetapkan oleh UU Pemerintah Daerah. 


\section{Kesimpulan}

Berdasarkan hasil penelitian dan pembahasan yang telah disampaikan di atas, berikut ini rumusan kesimpulan yang dapat disampaikan:

1) Iklim usaha dan kegiatan usaha yang kondusif bagi daerah dipengaruhi oleh adanya peraturan daerah yang mengatur tentang struktur organisasi daerah, yaitu faktor yang menentukan dalam penyelenggaraan pemerintahan di daerah, dan tata kelola pemerintahan yang dapat memberikan jaminan pelayanan publik yang baik.

2) Untuk mendorong iklim usaha dan investasi yang kondusif di daerah, maka diperlukan produk peraturan daerah yang mempunyai karakteristik : a) memiliki kesesuaian dengan peraturan-peraturan yang lebih tinggi yang berlaku; b) tidak mengakibatkan hambatan lalu-lintas distribusi barang dan atau jasa yang bersifat tarif maupun non tarif (tidak bertentangan dengan free internal trade principle); c)tidak mengakibatkan pungutan berganda (double taxation) dengan Pajak-pajak Pusat (PPh, PPN, PBB, dll) atau dengan Pajak/ Retribusi Daerah lainnya; d) besaran tarifnya berada dalam batas kewajaran sehingga tidak mengakibatkan ekonomi biaya tinggi; e) tidak diskriminatif. Perda yang tidak mengakibatkan penguasaan ekonomi pada kelompok-kelompok orang (tidak berpotensi menciptakan struktur pasar yang monopolis dan oligopolis); f) tidak mengharuskan atau mewajibkan investor untuk menjalin kemitraan dengan mitra lokal dari daerah yang bersangkutan; g) menjamin kepastian hukum dan menjamin setiap orang mempunyai kedudukan yang sama di mata hukum; h) menjamin kepastian standar pelayanan (perda-perda yang berkaitan dengan perizinan); dan i) perda yang ramah terhadap lingkungan, yaitu perda yang mendukung pengelelolaan sumber daya alam dengan baik agar sumber daya alam dapat dimanfaatkan secara optimal dan berkelanjutan.

3) Penyelenggaraan pemerintahan daerah kabupaten dan kota berdasarkan asas otonomi dan kewenangan desentralisasi pada prinsipnya memberi ruang yang cukup untuk dapat mengelola segala keperluan daerah berdasarkan kemampuan yang dimiliki oleh daerah. Ruang gerak yang diberikan kepada daerah memberikan kepercayaan kepada daerah untuk berperanserta dalam proses-proses perumusan dan pelaksanaan kebijakan di bidang pemerintahan, pembangunan daerah, dan kemasyarakatan yang sesuai dengan kebutuhan masyarakat daerah. 


\section{Saran}

Terkait dengan hasil penelitian dan pembahasan serta rumusan kesimpulan yang telah disampaikan, maka beberapa saran yang relevan untuk direalisasikan oleh pemerintah, lembaga-lembaga yang terkait, maupun masyarakat sebagai partisipan dalam praktek regulasi daerah yang kondusif bagi investasi di daerah adalah sebagai berikut:

1) Pemerintah pusat dan daerah harus bersinergi dalam mensikoronkan produk regulasi di tingkat pusat dan daerah kabupaten kota, karena masih amat sedikit daerah yang secara seruis menyusun regulasi yang mampu mengundang investasi dari pemilik modal dengan mempromosikan potensi fiskal, sumber daya alam (SDA), dan sumber daya manusia (SDM) yang yang dimiliki untuk memprioritaskan pembangunan ekonomi daerahnya. Demikian juga pemerintah pusat yang belum secara optimal memfasitasi pembagunan ekonomi daerah dengan mengoptimalkan ekonomi daerah .

2) Pemerintah daerah kabupaten dan kota harus berinisiatif merevisi regulasi pajak dan retribusi yang substansi dan materi muatannya bertentangan dengan peraturan yang ada diatasnya. Demikian pula dengan materi muatan peraturan daerah atau kebijakan yang substansinya bertentangan dengan hirarkhi peraturan perundang-undangan yang ada diatasnya.

3) Pemerintah kabupaten dan kota dalam merumuskan dan menetapkan arah kebijakan reformasi dan penyelenggaraan pemerintahan di daerah harus berorientasi dan mengacu pada hubungan hierarkhi antara pemerintah pusat dan pemerintah daerah untuk mengoptimalkan potensi sumber daya manusia dan sumber daya alam yang dimiliki oleh daerah dalam mendukung pembangunan nasional.

\section{Daftar Pustaka}

Bagir Manan, Perjalanan Historis Pasal 18 UUD 1945, Unsika, Karawang, 1993 , Menyongsong Fajar Otonomi Daerah, Penerbit PSH Fakultas Hukum UII, Yogyakarta, 2002

Davey, K.J., Pembiayaan Pemerintah Daerah, Praktek-praktek Internasional dan Relevansinya Bagi Dunia Ketiga, Penerbit UI Press, Jakarta, 1988

Gabriel U. Iglesias, Implementation : The Problem of Achieving Results, Eropa, Manila, 1979 Grindle, Merilee and Thomas, John.W. 1991. Public Choices and Policy Change: The Political Economy of Reform in Developing Countries. The John Hopkins University Press, London.

IDS. 2001. Learning Initiative on Citizen Participation and Local Governance. Jakarta: IDS. Josef Riwu Kaho, Analisa Hubungan Pemerintah Pusat dan Daerah di Indonesia, Bina Aksara, Jakarta, 1991 
, Prospek Otonomi Daerah di Negara Republik Indonesia, Identifikasi Beberapa Faktor Yang Mempengaruhi Penyelenggaraannya, Rajawali Press, 2002

KPPOD, 2005. Laporan Penelitian Gambaran Iklim Usaha di 20 Daerah Kabupaten/Kota di Indonesia. Jakarta: KPPOD.

Krishmna Darumurti dan Umbu Rauta, Otonomi Daerah Perkembangan Pemikiran dan Pelaksanaan, Citra Aditya Bahkti, Bandung, 2000

Luwihono, Slamet (ed.), Perencanaan dan Penganggaran Partisipatif untuk Good Governance, Bandung: FPPM, 2006.

Partowidagdo, Widjajono, Memahami Analisis Kebijakan: Kasus Reformasi Indonesia, Bandung: Program Studi Pembangunan - ITB, 1999.

Roscoe Pound, The Task of Law, Franklin and Marshal College, Lancaster, Pensilvania, 1994

Rozali Abdullah, Pelaksanaan Otnomi Luas dan Isu Federalisme Sebagai Suatu Alternatif, Rajawali Press, Jakarta, 2002

Smith, S. and A. Martin, "Achieving Sustainability of Biological Conservation: Report of a GEF Thematic Review. Monitoring and Evaluation Working Paper I". Global Environment Facility, 2000.

Sumarto, Hetifah Sj, Inovasi, Partisipasi dan Good Governance, Jakarta: Yayasan Obor Indonesia, 2003.

Syaukani HR (ed.al), Otonomi Daerah Dalam Negara Kesatuan, Pustaka Pelajar, Jakarta, 2003

Thomson, Ken. 1946. From Neighborhood to Nation: The Democratic Foundations of Civil Society. Tufts University: University Press of New England.

Tifa Foundation, Identifikasi dan Pemetaan Inovasi Program Pemerintah Kabupaten Jembrana. Jakarta: Pusat Kajian Pembangunan Administrasi Daerah dan Kota FISIP UI.

Artikel dan Makalah

Arnstein, S, 'A Ladder of Citizen Participation in the USA', Journal of the Royal Town Planning Institute, 1971.

Armida Alisyahbana, Identifikasi Problematika Pelaksanaan UU No. 25 Tahun 1999 tentang Perimbangan Keuangan Antara Pemerintah Pusat dan Pemerintah Daerah, Makalah Seminar Nasional Dalam Rangka Lustrum IV Program Pasca sarjana Upad, Bandung, Tanggal 9 Agustus 1999

Bagir Manan, Hubungan Pusat Daerah Dalam Penyelenggaraan Otonomi Daerah, Seminar Nasional "Otonomi Daerah dan Perimbangan Antara Pusat dan Daerah, Hata Internasional Legal Concelours, Jakarta, Tanggal 20 Juli 1999 Identifikasi Problematika Pelaksanaan UU No. 22 Tahun 1999 tentang Pemerintah Daerah, Makalah Seminar Nasional Dalam Rangka Lustrum IV Program Pasca sarjana Upad, Bandung, Tanggal 9 Agustus 1999

Hetifah Sj Sumarto, "Membangun Partisipasi Warga dalam Tata Pemerintahan di Indonesia: Praktek, Kebijakan, dan Agenda", Local Government Support Program, Civil Society Strengthening Team, Jakarta 2008

Johanes Fernandez, Mencari Bentuk Otonomi Daerah dan Upaya Memacu Pembangunan Regional di Masa Depan, Jurnal Ilmu-ilmu Sosial No 2 Tahun 1992

KPPOD, Laporan Program Review Perda Tahap II, Kerjasama KPPOD-PEG US AID, Agustus, 2002

, "Panduan Perancangan dan Review Perda Ramah Investasi Proyek Perbaikan Iklim Investasi Daerah Melalui Penerapan Sistem Perijinan Terpadu dan Penyempurnaan Kualitas Perda" Proyek Bersama Komite Pemantauan 
Pelaksanaan Otonomi Daerah (KPPOD)- Europena Commision (EC)- Asosiasi Pemerintahan Kota Seluruh Indonesia, 2008

,"Panduan bagi Para Analis Perda untuk kajian Perda Kab. Serang, Kota Tangerang, Kota Bitung, dan Kota Tomohon dalam Proyek Perbaikan Iklim Investasi Daerah melalui Penerapan Sistem Perijinan Terpadu dan Penyempurnaan Kualitas Perda", KPPOD-EU-APEKSI, Jakarta 2008

LGSP, Seri Penguatan Legislatif, Legal Drafting: Penyusunan Peraturan Daerah, Local Government Support Program, 2007

, Seri Penguatan Legislatif: Legal Drafting, Penyusunan Peraturan Daerah, Buku Pegangan untuk DPRD, Local Governance Support Program, Jakarta, 2007

,"Reformasi Organsasi Pengelolaan Keuangan Daerah", Kajian Akademis, Kerjasama antara USAID, LGSP dan Direktorat Jenderal Pemerintahan Umum Departemen Dalam Negeri, Jakarta, 2008

Pantius D, Soeling, Pemberdayaan SDM untuk Peningkatan Pelayanan Publik, Bisnis Birokrasi No. 2/Vol III/Agustus/1997

Ratnawati "Tata Kelola Ekonomi Daerah" dalam KPPOD News, Edisi Januari-April 2008

Trilaksono Nugroho, Reformasi dan Reorietasi Kebijakan Otonomi Daerah dalam Perspektif Hubungan Pemerintah Pusat dan Daerah, Jurnal Administrasi Negara Universitas Brawijaya, Vol. I. No.1 September 2000

Utang Suwaryo, Deskripsi dan Interpretasi Otonomi Daerah Serta Prospeknya Pada Masa Yang Akan Datang (Pasca Orde Baru), Makalah Disampaikan Dalam Studi Nasional Mahasiswa FISIP Se Indonesia tentang Eksistensi dan Prospek Otonomi Daerah Pasca Orde Baru, Bandung, Tanggal 1-3 Desember 1998

Anonim, Himpunan Undang-undang tentang Otonomi Daerah Serta Peraturan Pelaksanaannya, Pustaka Antara, Jakarta, 2000

UU No. 34 Tahun 2000 tentang Perubahan Atas UU No. 18 Tahun 1997 tentang Pajak Daerah dan Retribusi Daerah

Anonim, Himpunan Peraturan Pemerintah tentang Pelaksanaan Otonomi Daerah, Pustaka Antara, Jakarta, 2000

Keputusan Menteri Dalam Negeri No 130-67 Tahun 2002 tentang Pengakuan Kewenangan Kabupaten dan Kota 